\title{
Herpetofauna of Montane Areas of Tanzania. 1. Results from Two Amphibian Surveys of Malundwe Mountain, Mikumi National Park
}

\author{
Lucinda P. Lawson ${ }^{1}$ and Leah Collett ${ }^{2}$ \\ ${ }^{1}$ USDA-ARS-CMAVE, 1600 S.W. 23rd Drive, Gainesville, FL 32608, USA \\ ${ }^{2}$ Animal \& Environmental Research Group, Department Life Sciences, Anglia Ruskin University, East Road Cambridge UK CBI \\ $1 P T$
}

\begin{abstract}
As part of a larger survey of flora and fauna of Malundwe, funded by Critical Ecosystems Partnership Fund, amphibians were collected on three separate surveys of this mountain between 2004 and 2007. These surveys constitute the first surveys for amphibians in this part of the Eastern Arc Mountains, a global biodiversity hotspot. Samples from these surveys revealed an amphibian fauna with links to the rest of the Eastern Arc Mountains. Only relatively few species were found during these surveys, probably due to a small cumulative sampling effort, lack of a permanent water source, and the very small size of this forest fragment. The amphibian fauna of Malundwe shares an affinity with the Uluguru Mountains, both in terms of species composition of each mountain block and genetic proximity for species with available population level data. I describe the species and associated microhabitat from the available voucher specimens resulting from the Malundwe surveys.
\end{abstract}

\section{Introduction}

Malundwe Mountain is a little-known and often overlooked massif of the Eastern Arc Mountain (EAM) chain in Tanzania. With a total forested area of only $4.5 \mathrm{~km}^{2}$, this section of afromontane rainforest is one of the smallest blocks in the chain, and one of only two protected by Tanzania National Parks (TANAPA) (Lovett \& Norton, 1989; Stanley et al., 2005). Recent surveys, funded through the Critical Ecosystems Partnership Fund (CEPF), have helped to document the floral and faunal diversity of this series of peaks and to explore the relationship to other mountain ranges in close proximity (e.g., the Uluguru and Udzungwa Mountains). This study constitutes the first survey of amphibians in this Eastern Arc Mountain fragment and, given the pattern of endemism in the region (Poynton et al., 2007; Blackburn, 2009; Blackburn \& Measey, 2009), is an important contribution to our understanding of amphibians in this global biodiversity hotspot (Myers et al., 2000).

\section{Study Area}

Malundwe Mountain is located approximately $300 \mathrm{~km}$ west of Dar es Salaam in southern Mikumi National Park (MNP) $\left(7^{\circ} 24^{\prime} \mathrm{S}, 37^{\circ} 18^{\prime} \mathrm{E}\right.$; Fig. 1$)$ in central/eastern Tanzania. The three peaks that make up this small range reach a maximum height of $1250 \mathrm{~m}$ elevation, with afromontane forests extending from the peak down to $800-900 \mathrm{~m}$ on the eastern slopes (Lovett \& Norton, 1989). The total amount of forested area, divided between two patches, is $4.5 \mathrm{~km}^{2}$, with a closed forest canopy height of 20-30 m (Lovett \& Norton, 1989). Along with the Taita Hills, this total forest area comprises one of the smallest patches of forest in the entire Eastern Arc (Newmark, 2002; Burgess et al., 2007). Malundwe is unique, however, in that the entire area of mid-elevation forest is naturally very small (unlike the Taita Hills, where deforestation is a major factor in the small area of extant forest) and has been isolated and protected in the middle of a large area of preserved savannah, likely never affected by human encroachment. There is only one source of groundwater among these peaks: a small stream flowing adjacent to the research camp area established for biodiversity surveys (Fig. 1) $\left(7^{\circ} 23.719^{\prime} \mathrm{S}\right.$, $37^{\circ} 18.279^{\prime} \mathrm{E}, 985 \mathrm{~m}$ ) (Stanley et al., 2007). This stream can also be encountered farther down the slope as a slow-moving stream/wetland near the base camp $\left(7^{\circ} 21.913^{\prime} \mathrm{S}, 37^{\circ} 17.338^{\prime} \mathrm{E}\right.$, $840 \mathrm{~m}$ ) (Stanley et al., 2007). The water source is not permanent and is often completely dry by August until the rainy season beginning in December (observation by Animal Behaviour Research Unit research team (ABRU), Mikumi National Park).

\section{Surveys}

The amphibians collected during survey work in 2007 were incidentally encountered during small mammal surveys through digging of pitfall lines (see Chapter 1 of this volume), 

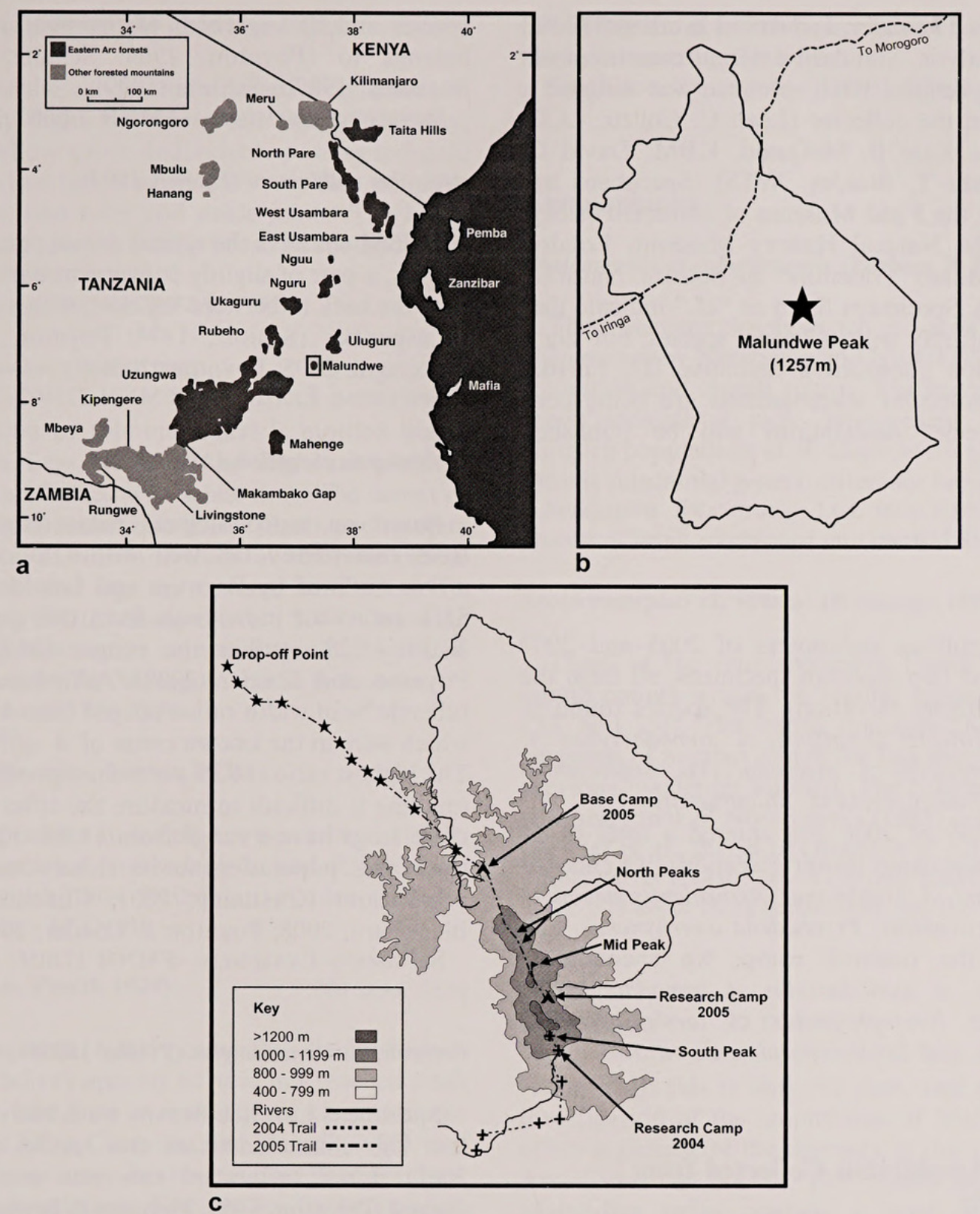

FIG. 1. Maps of the Eastern Arc Mountains with Malundwe boxed (a) and in Mikumi National Park in Tanzania (b); elevational map of Malundwe peak showing research camps (c). Figure created by Rebecca Banasiak and used with permission from Stanley et al. 2005.

collected in pitfall lines, and through chance encounters while walking. An additional incidental survey took place in 2004, but the material appears to have been lost. In contrast, in 2006, an effort was made to survey specifically for the herpetofauna of this region by including a herpetologist (Lawson) in the survey team. The 2005 survey was conducted in July (dry season) over a 10-day period (2005), with no concentrated effort collecting amphibians. The survey in 2006 was conducted over a seven-day period in early May (rainy season) with a distinct goal of cataloguing amphibians. The survey team followed the route of Stanley et al. (2007) to reach the Malundwe research camp with one night at the beginning of the survey and one night at the end of the survey at a base camp at the edge of the forested peaks $\left(7^{\circ} 21.913^{\prime} \mathrm{S}\right.$, $37^{\circ} 17.338^{\prime} \mathrm{E}, 840 \mathrm{~m}$ ), where we searched for amphibians in the evenings. We spent six nights at the research camp searching for amphibians night and day $\left(7^{\circ} 23.719^{\prime} \mathrm{S}\right.$, $\left.37^{\circ} 18.279^{\prime} \mathrm{E}, 985 \mathrm{~m}\right)$.

\section{Methods}

During the 2005 survey, caecilians and frogs were collected that were either recovered while installing pitfall buckets, caught in pitfall lines, or encountered while walking through the forest during the day. Herpetological surveys in 2006 were conducted primarily in areas within $200 \mathrm{~m}$ of water and extending along crests in the hills through pitfall lines. Each day, researchers searched for frogs among the leaf litter, on trees or other vegetation, and in the pitfall buckets. At night, researchers again searched leaf litter, trees, and low vegetation near water sources. Whenever possible, call recordings were made during the 2006 foray with a Marantz PMD660 Digital Recorder and linked to the associated specimen (FMNH collection). For processing specimens, each individual was first photographed and euthanized with MS222. Tissues were then taken from the liver and inner thigh and stored in DMSO buffer for molecular analysis. Specimens were then preserved 
in formalin (10\%), rinsed in water, and stored in ethanol (70\%) for morphological analysis. Standard external measurements were taken for each specimen. Each specimen was assigned a field number based on the collector (Leah C. Collett, LCC; Lucinda Lawson, LL; Kate B. McQuaid, KBM; David C. Moyer, DCM; William T. Stanley, WTS). Specimens are currently deposited at the Field Museum of Natural History, Chicago (FMNH); the Natural History Museum, London $(\mathrm{BMNH})$; and the Museo Tridentino di Scienze Naturali, Trento, Italy (MTSN). Specimens listed as "cf." indicate that the taxon shares an affinity with a known species, but slight morphological variation questions a definitive ID. Further morphological and molecular investigations are being conducted, and full species descriptions will be published following these studies.

\section{Results}

The incidental amphibian encounters of 2005 and 2007 yielded 13 anurans and two caecilian specimens, all from the research camp area (higher elevation). The species found in this survey are: Arthroleptis cf. affinis, A. stenodactylus, A. xenodactyloides, Probreviceps cf. macrodactylus, Scolecomorphus $\mathrm{cf}$. vittatus, and Boulengerula $\mathrm{cf}$. uluguruensis.

The week-long survey of 2006 encountered a total of 34 amphibians. At the base camp (lower elevation), we encountered Afrixalus fornasini, A. stuhlmanni, Arthroleptis stenodactylus, Hyperolius puncticulatus, Ptychadena oxyrhynchus, and Ptychadena sp. At the research camp, we encountered Arthroleptis cf. affinis, A. stenodactylus, A. xenodactyloides, Leptopelis uluguruensis, Nectophrynoides cf. tornieri, Boulengerula cf. uluguruensis, and Scolecomorphus cf. vittatus.

\section{Annotated List of Amphibians Collected from Malundwe Mountain}

Voucher specimens are referred to by Museum accession numbers where available and field numbers (e.g., WTS, LCC) for those yet to be accessioned at the Natural History Museum (NHM), London.

\section{Anurans}

\section{Afrixalus fornasini (Bianconi, 1849)}

The individual found possesses the dorsal color pattern of broad light bands from the nostrils to the urostyle separated by a thick, dark central band. Sides and feet are dark brown. The specimen is a large female with large, conspicuous, black-tipped asperities on head, back, and the dorsal surfaces of limbs. These characteristics, along with the tibia/snout-urostyle length (SUL) ratio of this specimen (45\%), correspond with Pickersgill's (2007) description. The head width/tibia ratio, however, is much higher than his description (106\% instead of the $51 \%-80 \%$ ratio described). The dorsal pattern of this individual clearly most closely resembles photos depicting $A$. fornasini as opposed to $A$. unicolor in Pickersgill (2007), which Pickersgill considers to be potentially a separate species. Further molecular work will be necessary to determine whether these are different species and, if so, which of the two species this individual belongs to (Poynton, 1964; Schiøtz, 1975; Poynton \& Broadley, 1987b; Schiøtz, 1999).

SPECIMENS EXAMINED-FMNH 275600.

\section{Afrixalus stuhlmanni (Pfeffer, 1893)}

Individuals have the typical dorsal pattern described for this species, a pair of slightly convergent dark lines from the rump over the back to between the eyes, with a scattered distribution of asperities (Schiøtz, 1974; Poynton \& Broadley, 1987a; Pickersgill, 2005; Poynton, 2006).

SPeCiMEnS Examined-FMNH 275602-275607.

\section{Arthroleptis cf. affinis (Ahl, 1939)}

Based on morphological measurements, the individuals from this survey fall well within the characteristics of $A$. affinis outlined by Poynton and Loader (2008). Head width/ SUL ratios for individuals from this collection ranged from $38.3 \%-45.2 \%$, within the ranges $(34.8 \%-45.9 \%)$ given by Poynton and Loader (2008). Additionally, inner metatarsal tubercle/head width ratios ranged from $11.3 \%-14.2 \%$, most of which were in the known range of $A$. affinis of $8.70 \%-13.77 \%$. The highest ratio $(14.2 \%)$ is from a poorly preserved specimen (making it difficult to measure the tubercle), and if excluded, these frogs have a range from $11.3 \%-12.6 \%$. Molecular data show this population to be closely associated to Uluguru populations (Channing, 2001; Channing \& Howell, 2006; Blackburn, 2008; Poynton \& Loader, 2008).

SPECIMENS EXAMINED-FMNH 272056; WTS 6768, 6795, 6820, 6832; LCC 009 .

\section{Arthroleptis stenodactylus (Pfeffer 1893)}

Specimens have the heavily built body with relatively short rear legs characteristic of this species (Poynton \& Loader, 2008). Inner metatarsal tubercles are distinct and shovel shaped (Poynton, 1964; Poynton \& Broadley, 1985; Channing, 2001; Channing \& Howell, 2006).

SPECIMENS EXAMINED-FMNH 272054, 272055, 275599; LCC 011, 013; WTS 6850.

\section{Arthroleptis xenodactyloides (Hewitt 1933)}

Adults from this collection range in size from 12.95 to $19.10 \mathrm{~mm}$. Dorsal coloration on some individuals is mottled brown with banded arms and legs. Ventral surface of limbs and throat are gray/pink. Ventral surface is white/gold. Digits have small distinct discs in a teardrop shape, and hands and feet are marked with many tubercles (Poynton, 1964; Poynton \& Broadley, 1985; Channing, 2001; Channing \& Howell, 2006).

SPECIMENS EXAMINED-WTS 6802, 6764 6756; FMNH 272057.

\section{Hyperolius puncticulatus (Pfeffer 1893)}

Although the pattern in $H$. puncticulatus can be variable, the Malundwe population appears solely to exhibit the most common color morph: yellow dorsum with conspicuous blacklined canthal and dorsolateral stripes (Schiøtz, 1975; Poynton \& Broadley, 1987c; Schiøtz, 1999).

SPECIMENS EXAMINED-FMNH 274351-274359. 


\section{Leptopelis uluguruensis (Barbour and Loveridge 1928)}

Dorsal coloration of these individuals ranged from a browngreen background at night to blue-green during the day, mottled with small yellow spots. Individuals possess red-gold pupils/iris. The ventral surface is white with very blue points at shoulder joints, waist, and knee and ankle joints. The heads are characteristic of the species, with a broad shape and short nose (Schiøtz, 1975, 1999).

SPECIMENS EXAMINED-FMNH 275626-275628.

\section{Nectophrynoides cf. tornieri (Roux 1906)}

The dorsal coloration of this individual is mottled black/ brown, with dark sides. Legs, feet, toes, and thighs are speckled. Ventral side is dark and flecked with white dots. The throat of this individual is pale grey with white flecks. Groin and toes are pink. Eyes are golden. The head is thick at the base (spade shaped), and the back and legs are covered in small warts (Roux, 1906; Channing, 2001; Menegon et al., 2004; Channing \& Howell, 2006). The taxonomic status of this individual is currently being assessed by M. Menegon and S. P. Loader.

SPECIMENS EXAMINED-MTSN 7329.

\section{Probreviceps cf. macrodactylus (Nieden, 1926)}

This is a juvenile specimen in which a tympanum is visible. Juveniles of the subspecies $P$. macrodactylus and $P$. loveridgei are difficult to distinguish; thus, further surveys are needed.

SPeCIMENS EXAMINED-LCC 010.

\section{Ptychadena oxyrhynchus (Smith 1849)}

Although this specimen (and potentially the unknown Ptychedena sp. listed below) appears to have not reached adult size, it is identifiable based on morphological characteristics outlined in Channing (2001), Channing and Howell (2006), and Pickersgill (2007). This specimen has several dorsolateral ridges, and as fitting with the description of the species, the two median ridges begin at the posterior of the eye and end in the middle of the back. Distal to these medial ridges, two other ridges extend from behind the eyes and continue to the vent. The tympanum (typ) is clearly visible, and it reaches almost the eye diameter (typ/ eye $=0.88$, in line with the described range of $0.8-1.0$ ). The hind legs are long and muscular as described for the species; the ratio of femur/SUL is $57 \%$. The tibia/SUL ratio is also slightly small, $63 \%$ as opposed to $0.7-0.8$ (Channing 2001), or $67 \%-77 \%$ (Pickersgill 2007). Foot and longest toe measurements, however, are slightly high $(0.92)$ for the range $(0.8-0.9)$. Toe-tips and finger-tips are not enlarged. Eye diameter $=4.69 \mathrm{~mm}$, tympanum width $=4.12 \mathrm{~mm}$ (tympanum height $=3.5 \mathrm{~mm})$. Femur $=$ $22.2 \mathrm{~mm}$, tibia $=24.6 \mathrm{~mm}$, foot $=35.77 \mathrm{~mm}$, inner metatarsal $=$ $3.00 \mathrm{~mm}$. The distance from the nostrils to the snout is approximately equal to the internarial distance. This specimen is dark green/brown with gold ridges down the back. Speckled brown/cream sides. The upper section of the iris is golden, throat and dorsal surfaces white. Underside of thighs pinkish with cream spots. Back of thigh had light and dark longitudinal bands (Schmidt \& Inger, 1959; Poynton, 1964; Inger, 1968; Channing, 2001; Channing \& Howell, 2006; Pickersgill, 2007).

SPECIMENS EXAMINED-FMNH 275593.

A second possible $P$. oxyrhynchus specimen was also found, although as a juvenile, the identity is uncertain. The specimen has a long snout and three horizontal bands on the back of the thighs connecting the knees.

SPECIMENS EXAMINED-FMNH 275601.

\section{Gymnophiona}

\section{Boulengerula cf. uluguruensis (Barbour \& Loveridge 1935)}

The specimens closely match the description of Boulengerula uluguruensis by Nussbaum and Hinkel (1994), particularly in the coloration and annuli counts. Furthermore, Loader et al. (in press) indicate a close phylogenetic relationship between Uluguru populations of $B$. uluguruensis to Malundwe, although there is substantial genetic difference between these populations.

SPeCIMENS EXAMINED-LCC 003; KBM 003. These are in the process of being accessioned into the BMNH collection.

\section{Scolecomorphus cf. vittatus (Boulenger 1895)}

Three of the four specimens found for this species have annuli counts within the regular range for this species (130, 133, and 136). The fourth specimen (KBM 005) extends the variation of number annuli for this species to 150 (148 was the previous maximum known). The coloration of the specimens resembles that of Nussbaum's (1985) description of S. vittatus (Loader et al., 2003a,b; Gower et al., 2004).

SPECIMENS EXAMINED-LCC 004; KBM 002, 004, 005. These are in the process of being accessioned into the BMNH collection.

\section{Discussion}

Although this is only the first, and relatively preliminary, investigation of the amphibians of Malundwe, the collection offers a glimpse of the diversity in this poorly known Eastern Arc forest fragment. The small isolated peaks of the Malundwe range contain a small subset of the known amphibian diversity of larger Eastern Arc Mountains (Table 1). This reduced biodiversity may be a result of the small size of this fragment, which is a fraction of the size of most others in this system. For example, Malundwe has a total forested area of $4.5 \mathrm{~km}^{2}$, whereas the other mountains, although heavily deforested in many cases, are hundreds of square kilometers. Pare Mountains have $484 \mathrm{~km}^{2}$ of forest, West Usambara $328 \mathrm{~km}^{2}$, East Usambara $413 \mathrm{~km}^{2}$, Nguru $647 \mathrm{~km}^{2}$ including Nguu, Ukaguru $184 \mathrm{~km}^{2}$, Uluguru $527 \mathrm{~km}^{2}$, Rubeho $499 \mathrm{~km}^{2}$, Udzungwa $1960 \mathrm{~km}^{2}$, and Mahenge $291 \mathrm{~km}^{2}$ (Newmark, 1998). The Taita Hills are the only comparable area with just $6 \mathrm{~km}^{2}$ of forest, although the original amount was much greater. In comparing Malundwe species diversity to lists from the Udzungwa, Uluguru (Malundwe's nearest neighbor), and the East Usambara Mountains, it is apparent that the species encountered at Malundwe appear to be the omnipresent types, found on many mountain areas throughout the EAM. When species are shared between a subset of mountains and Malundwe, those on Malundwe appear to be more similar to the northern localities (the Uluguru Mountains and the East Usambara) than the southern locality (Udzungwa). Based on molecular datasets, preliminary work on Boulengerula uluguruensis and Hyperolius puncticulatus suggests that Malundwe populations show the closest phylo- 
TABLE 1. Comparison of amphibians encountered on Malundwe Mountain and lists compiled from the literature and chapters in this edited volume from the East Usambara, Uluguru, and Udzungwa Mountains.

\begin{tabular}{|c|c|c|c|c|}
\hline & Udzungwa & Malundwe & East Usambara & Uluguru \\
\hline \multicolumn{5}{|l|}{ Anura } \\
\hline Afrixalus brachycnemis & $\mathrm{x}$ & & $\mathrm{x}$ & $\mathrm{x}$ \\
\hline Afrixalus delicatus & $\mathrm{x}$ & & & $\mathrm{x}$ \\
\hline Afrixalus fornasini & $\mathrm{x}$ & $\mathrm{x}$ & $\mathrm{x}$ & $\mathrm{x}$ \\
\hline Afrixalus morerei & $\mathrm{x}$ & & & \\
\hline Afrixalus stuhlmanni & & $\mathrm{x}$ & $\mathrm{x}$ & $\mathrm{x}$ \\
\hline Afrixalus uluguruensis & $\mathrm{x}$ & & $\mathrm{x}$ & $\mathrm{x}$ \\
\hline Amietia angolensis & $\mathrm{x}$ & & $\mathrm{x}$ & $\mathrm{x}$ \\
\hline Amietophrynus gutturalis & $\mathrm{x}$ & & $\mathrm{x}$ & $\mathrm{x}$ \\
\hline Amietophrynus maculatus & $\mathrm{x}$ & & $\mathrm{x}$ & $\mathrm{x}$ \\
\hline Arthroleptides martiensseni & & & $\mathrm{x}$ & \\
\hline Arthroleptis affinis & $\mathrm{x}$ & $\mathrm{x}$ & $\mathrm{x}$ & $\mathrm{x}$ \\
\hline Arthroleptis reichei & $\mathrm{x}$ & & & \\
\hline Arthroleptis stenodactylus & $\mathrm{x}$ & $\mathrm{x}$ & $\mathrm{x}$ & $\mathrm{x}$ \\
\hline Arthroleptis xenodactyloides & $\mathrm{x}$ & $\mathrm{x}$ & $\mathrm{x}$ & $\mathrm{x}$ \\
\hline Arthroleptis xenodactylus & & & $\mathrm{x}$ & \\
\hline Arthroleptides yakusini & $\mathrm{x}$ & & & $\mathrm{x}$ \\
\hline Breviceps mossambicus & $\mathrm{x}$ & & $\mathrm{x}$ & \\
\hline Bufo brauni & $\mathrm{x}$ & & $\mathrm{x}$ & $\mathrm{x}$ \\
\hline Bufo lindneri & $\mathrm{x}$ & & & \\
\hline Callulina kreffti & $\mathrm{x}$ & & $\mathrm{x}$ & $\mathrm{x}$ \\
\hline Chiromantis xerampelina & $\mathrm{x}$ & & $\mathrm{x}$ & $\mathrm{x}$ \\
\hline Hemisus marmoratus & $\mathrm{x}$ & & $\mathrm{x}$ & \\
\hline Hildebrandtia ornata & $\mathrm{x}$ & & & \\
\hline Hoplophryne rogersi & & & $\mathrm{x}$ & \\
\hline Hoplophryne uluguruensis & $\mathrm{x}$ & & & $\mathrm{x}$ \\
\hline Hyperolius argus & & & $\mathrm{x}$ & \\
\hline Hyperolius kihangensis & $\mathrm{x}$ & & & \\
\hline Hyperolius minutisimus & $\mathrm{x}$ & & & \\
\hline Hyperolius mitchelli & $\mathrm{x}$ & & $\mathrm{x}$ & $\mathrm{x}$ \\
\hline Hyperolius parkeri & $\mathrm{x}$ & & $\mathrm{x}$ & \\
\hline Hyperolius pictus & $\mathrm{x}$ & & & \\
\hline Hyperolius puncticulatus & $\mathrm{x}$ & $\mathrm{x}$ & $\mathrm{x}$ & $\mathrm{x}$ \\
\hline Hyperolius spinigularis & & & $\mathrm{x}$ & $\mathrm{x}$ \\
\hline Hyperolius tuberilinguis & $\mathrm{x}$ & & $\mathrm{x}$ & \\
\hline Hyperolius mariae & & & $\mathrm{x}$ & \\
\hline Kassina maculata & $\mathrm{x}$ & & $\mathrm{x}$ & \\
\hline Kassina senegalensis & $\mathrm{x}$ & & $\mathrm{x}$ & \\
\hline Leptopelis barbouri & $\mathrm{x}$ & & $\mathrm{x}$ & \\
\hline Leptopelis flavomaculatus & $\mathrm{x}$ & & $\mathrm{x}$ & $\mathrm{x}$ \\
\hline Leptopelis parkeri & $\mathrm{x}$ & & $\mathrm{x}$ & $\mathrm{x}$ \\
\hline Leptopelis uluguruensis & $\mathrm{x}$ & $\mathrm{x}$ & $\mathrm{x}$ & $\mathrm{x}$ \\
\hline Leptopelis vermiculatus & $\mathrm{x}$ & & $\mathrm{x}$ & \\
\hline Mertensophryne micranotis & & & $\mathrm{x}$ & $\mathrm{x}$ \\
\hline Nectophrynoides asperginis & $\mathrm{x}$ & & & \\
\hline Nectophrynoides cryptus & & & & $\mathrm{x}$ \\
\hline Nectophrynoides frontierei & & & $\mathrm{x}$ & \\
\hline Nectophrynoides laevis & & & & $\mathrm{x}$ \\
\hline Nectophrynoides minutus & & & & $\mathrm{x}$ \\
\hline Nectophrynoides poyntoni & $\mathrm{x}$ & & & \\
\hline Nectophrynoides pseudotornieri & & & & $\mathrm{x}$ \\
\hline Nectophrynoides tornieri & $\mathrm{x}$ & $\mathrm{x}$ & $\mathrm{x}$ & $\mathrm{x}$ \\
\hline Nectophrynoides viviparus & $\mathrm{x}$ & & & $\mathrm{x}$ \\
\hline Nectophrynoides wendyae & $\mathrm{x}$ & & & \\
\hline Parhoplophryne usambarica & & & $\mathrm{x}$ & \\
\hline Phrynobatrachus acridoides & $\mathrm{x}$ & & $\mathrm{x}$ & $\mathrm{x}$ \\
\hline Phrynobatrachus kreffti & & & $\mathrm{x}$ & \\
\hline Phrynobatrachus mababiensis & $\mathrm{x}$ & & & \\
\hline Phrynobatrachus natalensis & $\mathrm{x}$ & & & $\mathrm{x}$ \\
\hline Phrynobatrachus parvulus & $\mathrm{x}$ & & & \\
\hline Phrynobatrachus rungwensis & $\mathrm{x}$ & & & \\
\hline Phrynobatrachus uzungwensis & $\mathrm{x}$ & & & $\mathrm{x}$ \\
\hline Probreviceps macrodactylus & $\mathrm{x}$ & & $\mathrm{x}$ & $\mathrm{x}$ \\
\hline Probreviceps rungwensis & $\mathrm{x}$ & & & \\
\hline Probreviceps uluguruensis & & & & $\mathrm{x}$ \\
\hline Ptychadena anchietae & $\mathrm{x}$ & & $\mathrm{x}$ & \\
\hline Ptychadena grandisonae & $\mathrm{x}$ & & & \\
\hline Ptychadena mascareniensis & & & $\mathrm{x}$ & \\
\hline Ptychadena mossambica & $\mathrm{x}$ & & & \\
\hline Ptychadena oxyrhynchus & & $\mathrm{x}$ & $\mathrm{x}$ & $\mathrm{x}$ \\
\hline Ptychadena porosissima & $\mathrm{x}$ & & & \\
\hline
\end{tabular}


TABLE 1. Continued

\begin{tabular}{lccc}
\hline & Udzungwa & Malundwe & East Usambara \\
\hline Ptychadena taenioscelis & $\mathrm{x}$ & & \\
Ptychadena uzungwensis & $\mathrm{x}$ & & $\mathrm{x}$ \\
Pyxicephalus edulis & $\mathrm{x}$ & & \\
Schismaderma carens & $\mathrm{x}$ & $\mathrm{x}$ & \\
Spelaeophryne methneri & $\mathrm{x}$ & & $\mathrm{x}$ \\
Stephopaedes usambarae & $\mathrm{x}$ & $\mathrm{x}$ & \\
Strongylopus fuelleborni & $\mathrm{x}$ & & $\mathrm{x}$ \\
Xenopus laevis & $\mathrm{x}$ & $\mathrm{x}$ & \\
Xenopus mulleri & & $\mathrm{x}$ & $\mathrm{x}$ \\
Xenopus cf. petersii & & & $\mathrm{x}$ \\
Gymnophiona & & $\mathrm{x}$ & \\
Scolecomorphus vittatus & $\mathrm{x}$ & & \\
Boulengerula ulugurensis & & & \\
Boulengerula boulengeri & & \\
Scolecomorphus kirkii & & \\
Scolecomorphus uluguruensis & & & $\mathrm{x}$ \\
\hline
\end{tabular}

genetic relationships to Uluguru populations (Lawson, 2010; Loader et al., in press). The similarity of the overall amphibian communities and the low genetic diversity between populations of species on Malundwe and the Uluguru Mountains indicate that these forest fragments are among some of the more closely related but separated areas within the Eastern Arc system (Loader et al., 2004; Poynton et al., 2007; M. Menegon, unpubl. data). Unfortunately, species lists throughout the Eastern Arc are too incomplete and mountain ranges too unevenly sampled to make broad comparisons of assemblages (Poynton et al., 2007).

The Malundwe block is one of the smallest of the Eastern Arc blocks and has been found to be completely without water during the dry season (L. Collett, pers. com.: dry season foray by ABRU team, 2004). Both the small total forest area and the potential vulnerability of the area to drought might mean that amphibian populations in Malundwe may not be stable through time, possibly acting as a metapopulation sink with the genetically and spatially proximal Uluguru Mountains. The description of the Malundwe Mountain amphibians fills a gap in our understanding of endemism and species distributions throughout the Eastern Arc, addressing connectivity between northern and southern mountain populations. With focused sampling effort, the biogeographical connections of Malundwe with the other Eastern Arc fragments and the distinctiveness of its amphibian assemblage will aid biologists and conservationists in understanding the diversity within this dynamic area. Although, at present, Malundwe appears to only have widespread species, a closer examination may reveal some of those to be specifically distinct from other EAM species and endemic to Malundwe.

\section{Acknowledgments}

I thank the researchers at the Animal Behaviour Research Unit (ABRU) in Mikumi National Park for inviting me to accompany them on collecting amphibians in Mikumi. Their exceptional planning and dedication to the project made the endeavor possible. Although all members of the ABRU team throughout the years have made valuable contributions to science in many ways, the members of the ABRU team at the time of this study (Leah, Abi, Kate, and
Christie) were a delight to work with. In addition, I thank Elia Mulungu for his assistance in the field and D. Moyer for organizing my participation. Special thanks to W. Stanley for training the ABRU team and establishing the research camps. Financial support was provided through a grant from the Critical Ecosystems Partnership Fund entitled "Malundwe's Afromontane Forest and River Catchments: Discovery and Capacity Building" awarded to Anglia Ruskin University. Research was conducted with permits and assistance from COSTECH, TANAPA and TAWIRI. All Malundwe surveys were designed in collaboration with Mikumi National Park with significant support from wardens and rangers especially John Shemkunde (Chief Park Warden) and Fredrick Mofulu (Park Ecologist). We would like to specially acknowledge Dr. Guy Norton, the Principal Investigator of this project and director of ABRU for his continued dedication to the exploration and preservation of this special place.

\section{Literature Cited}

BlackBurn, D. C. 2008. Biogeography and evolution of body size and life history of African frogs: Phylogeny of squeakers (Arthroleptis) and long-fingered frogs (Cardioglossa) estimated from mitochondrial data. Molecular Phylogenetics and Evolution, 49: 806-826.

2009. Description and phylogenetic relationships of two new species of miniature Arthroleptis (Anura: Arthroleptidae) from the Eastern Arc Mountains of Tanzania. Breviora, 517: 1-17.

Blackburn, D. C., and G. J. Measey. 2009. Dispersal to or from an African biodiversity hotspot? Molecular Ecology, 18: 1904-1915.

Burgess, N. D., T. M. Butynski, N. J. Cordeiro, N. H. Doggart, J. Fueldså, K. M. Howell, F. B. Kilahama, N. D. S. P. Loader, J. C. Lovett, B. Mbilinyi, M. Menegon, D. C. Moyer, E. Nashanda, A. Perkin, F. Rovero, W. T. Stanley, and S. N. Stuart. 2007. The biological importance of the Eastern Arc Mountains of Tanzania and Kenya. Biological Conservation, 134: 209-231.

Channing, A. 2001. Amphibians of Central and Southern Africa. Cornell University Press, Ithaca, New York.

Channing, A., And K. M. Howell. 2006. Amphibians of East Africa. Cornell University Press, Ithaca, New York.

Gower, D. J., S. P. Loader, C. B. MoncriefF, And M. Wilkinson. 2004. Niche separation and comparative abundance of Boulengerula boulengeri and Scolecomorphus vittatus (Amphibia: Gymnophiona) in an East Usambara forest, Tanzania. African Journal of Herpetology, 53: 183-190. 
Inger, R. F. 1968. Amphibia. Exploration du Parc National de la Garamba, Mission H. De Saeger (1949-1952). Kinshasa: Institut des Parcs Nationaux, 52: 1-190.

Lawson, L. P. 2010. The discordance of diversification: evolution in the tropical-montane frogs of the Eastern Arc Mountains of Tanzania. Molecular Ecology, 19: 4046-4060.

Loader, S. P., D. J. Gower, K. M. Howell, N. Doggart, M. O. Rödel, B. T. Clarke, R. O. de Sa., B. L. Cohen, and M. WILKINSON. 2004. Phylogenetic relationships of African microhylid frogs inferred from DNA sequences of mitochondrial $12 \mathrm{~S}$ and $16 \mathrm{~S}$ rRNA genes. Organisms Diversity \& Evolution, 4: 227-235.

Loader, S. P., D. J. Gower, AND M. Wilkinson. 2003a. Caecilians: Mysterious amphibians of the Eastern Arc Mountains. Arc Journal, 15: 3-4.

Loader, S. P., M. Wilkinson, J. A. Cotton, H. Müller, M. Menegon, K. M. Howell, and D. J. Gower. In press. Molecular phylogenetics of Boulengerula (Amphibia: Gymnophiona: Caeciliidae) and implications for taxonomy, biogeography and conservation. Herpetological Journal.

Loader, S. P., M. Wilkinson, D. J. Gower, And C. A. Msuya. 2003b. A remarkable young Scolecomorphus vittatus (Amphibia: Gymnophiona: Scolecomorphidae) from the North Pare Mountains, Tanzania. Journal of Zoology, 259: 93-101.

Lovett, J. C., AND G. W. Norton. 1989. Afromontane rainforest on Malundwe Hill in Mikumi National Park, Tanzania. Biological Conservation, 48: 13-19.

Menegon, M., S. Salvidio, and S. P. Loader. 2004. Five new species of Nectophrynoides Noble 1926 (Amphibia Anura Bufonidae) from the Eastern Arc Mountains, Tanzania. Tropical Zoology, 17: 97-121.

Myers, N., R. A. Mittermeier, C. G. Mittermeier, G. A. B. DA FonseCA, AND J. KENT. 2000. Biodiversity hotspots for conservation priorities. Nature, 403: 853-858.

NeWMARK, W. D. 1998. Forest area, fragmentation, and loss in the Eastern Arc Mountains: Implications for the conservation of biological diversity. Journal of the East African Natural History Society, 87: 29-36.

2002. Conserving biodiversity in East African forests: A study of the Eastern Arc Mountains. Springer Verlag, Heidelberg.

Nussbaum, R. 1985. Systematics of caecilians (Amphibia: Gymnophiona) of the family Scolecomorphidae. Occasional Papers of the Museum of Zoology, University of Michigan, 713: 1-49.

Nussbaum, R. A., and H. Hinkel. 1994. Revision of East African caecilians of the genera Afrocaecilia Taylor and Boulengerula Tornier (Amphibia: Gymnophiona: Caeciliaidae). Copeia, 3: $750-760$

Pickersgill, M. 2005. The taxonomy and ethology of the Afrixalus stuhlmanni complex (Anura: Hyperoliidae). Steenstrupia, 29: 1-38.
2007. Frog Search: Results of Expeditions to Southern and Eastern Africa. Edition Chimaira, Frankfurt.

Poynton, J. C. 1964. The Amphibia of South Africa. Annals of the Natal Museum, 17: 1-334.

2006. On Dwarf Spiny Reedfrogs in Tanzanian Eastern Lowlands (Anura: Afrixalus): Short communication. African Journal of Herpetology, 55: 167-169.

Poynton, J. C., and D. G. Broadley. 1985. Amphibia Zambesiaca 1. Scolecomorphidae, Pipidae, Microhylidae, Hemisidae, Arthroleptidae. Annals of the Natal Museum, 26: 503-553.

1987a. Amphibia Zambesiaca 3. Rhacophoridae and Hyperoliidae. Annals of the Natal Museum, 28: 161-229.

1987b. Amphibia Zambesiaca 3. Rhacophoridae and Hyperoliidae. Annals of the Natal Museum, 28: 192-193.

- 1987c. Amphibia Zambesiaca 3. Rhacophoridae and Hyperoliidae. Annals of the Natal Museum, 28: 161-229.

Poynton, J. C., AND S. P. LoAder. 2008. Clinal variation and its taxonomic consequences in the common Tanzanian forest frog, Arthroleptis affinis. Copeia, 3: 517-526.

Poynton, J. C., S. P. Loader, E. Sherratt, and B. T. Clarke. 2007. Amphibian diversity in East African biodiversity hotspots: Altitudinal and latitudinal patterns. Biodiversity and Conservation, 16: $1103-1118$.

Roux, J. 1906. Synopsis of the toads of the genus Nectophryne B. \& P., with special remarks on some known species and descriptions of a new species from German East Africa. Proceedings of the Zoological Society of London, 1906: 58-65.

Schiøтz, A. 1974. Revision of the genus Afrixalus (Anura) in eastern Africa. Videnskabelige meddelelser fra Dansk naturhistorisk forening, 137: 9-18.

. 1975. The Treefrogs of Eastern Africa. Steenstrupia, Copenhagen.

. 1999. Treefrogs of Africa. Edition Chimaira, Frankfurt am Main.

SCHMIDT, K. P., AND R. F. Inger. 1959. Amphibians exclusive of the genera Afrixalus and Hyperolius. Exploration du Parc National de l'Upemba. Mission GF de Witte, en Collaboration avec W. Adam, A. Janssens, L. van Meel et R. Verheyen (1946-1949), 56: $1-264$.

Stanley, W. T., J. Gunn, and P. M. Kihaule. 2005. Results of a preliminary small mammal survey of Malundwe Mountain, Mikumi National Park, Tanzania. Journal of East African Natural History, 94: 213-222.

Stanley, W. T., G. W. Norton, P. M. Kihaule, L. Collett, and K. McQuAID. 2007. Additional notes on the small mammals of Malundwe Mountains, Mikumi National Park, Tanzania. Journal of East African Natural History, 96: 203-214. 


\section{$2 \mathrm{BHL}$ Biodiversity Heritage Library}

Lawson, Lucinda P and Collett, Leah. 2011. "Herpetofauna of Montane Areas of Tanzania. 1. Results from Two Amphibian Surveys of Malundwe Mountain, Mikumi National Park." Fieldiana 4, 74-80.

https://doi.org/10.3158/2158-5520-4.1.74.

View This Item Online: https://www.biodiversitylibrary.org/item/281135

DOI: https://doi.org/10.3158/2158-5520-4.1.74

Permalink: https://www.biodiversitylibrary.org/partpdf/296982

\section{Holding Institution}

Field Museum of Natural History Library

\section{Sponsored by}

Field Museum of Natural History Library

\section{Copyright \& Reuse}

Copyright Status: In copyright. Digitized with the permission of the rights holder.

License: http://creativecommons.org/licenses/by-nc-sa/4.0/

Rights: http://biodiversitylibrary.org/permissions

This document was created from content at the Biodiversity Heritage Library, the world's largest open access digital library for biodiversity literature and archives. Visit BHL at https://www.biodiversitylibrary.org. 